\title{
Biopesticidal Effect of Partitioned Extracts of \\ Zanthoxylum zanthoxyloides (Lam.) Zepernick \& Timler on Callosobruchus maculatus (Fab.)
}

\author{
Mohammed Gbate (correspondence author) \\ Federal Polytechnic, Bida, Nigeria \\ E-mail: gbatenda@gmail.com \\ Tel: 07031037828 \\ Olufemi Michael Ashamo \\ Federal University of Technology, Akure, Nigeria \\ E-mail: oashamo@yahoo.com \\ Tel: 08035019708 \\ Akinwande Lawrence Kayode \\ Federal University of Technology, Akure, Nigeria \\ E-mail: akinkay20032001@yahoo.com
}

Tel: 08030650537

Received: June 17, $2021 \quad$ Accepted: July 11, $2021 \quad$ Published: July 17, 2021

doi:10.5296/jas.v9i3.18867

URL: https://doi.org/10.5296/jas.v9i3.18867

\begin{abstract}
Botanicals have become the focus for discovery of novel bioinsecticides for protection of crops most especially because of their biodegradability, non-toxicity, target organism specificity and environmental friendliness. Partitioned extracts of Zanthoxylum zanthoxyloides were investigated for biopesticidal effect on Callosobruchus maculatus with aim of identifying the most active components and increase ease of handling when compared to bulk crude plant material used by farmers. Crude powder of rootbark of Z. zanthoxyloides was made as well as partitioned extracts using Kupchan partition extraction methods with methanol, acetone, ethyl acetate and n-hexane as solvents. Analysis of the rootbark of the plant showed $19.87 \%$ ash content, $24 \%$ crude protein, $24.85 \%$ crude fibre, $3.13 \%$ oil extract, $15.42 \mathrm{mg} / 100 \mathrm{~g}$ alkaloids, $45.90 \mathrm{mg} / 100 \mathrm{~g}$ tannins, $1039.14 \mathrm{mg} / 100 \mathrm{~g}$ saponins, $26.47 \mathrm{mg} / 100 \mathrm{~g}$ flavonoids, $150.0 \mathrm{mg} / 100 \mathrm{~g}$ iron, $244.70 \mathrm{mg} / 100 \mathrm{~g}$ calcium, $36.65 \mathrm{mg} / 100 \mathrm{~g}$ magnesium, $449.00 \mathrm{mg} / 100 \mathrm{~g}$ potassium and $128.30 \mathrm{mg} / 100 \mathrm{~g}$ of phosphorus. The crude powder and
\end{abstract}


extracts were bioassayed on $C$. maculatus in stored cowpea. Insecticidal activities of the partitioned extracts increased with increasing concentration; toxicity test revealed that n-hexane at $1 \%, 2 \%$ and $3 \%$, acetone extract at $3 \%$, and crude powder at $1.5 \mathrm{~g}$ all have same effect on the insect as the positive control, achieving $100 \%$ mortality at 24 hours post treatment, number of adult emergence of 63.57 was recorded with $1 \%$ methanol extract against 28 in $3 \%$ of the extract. There was a significant difference in weight loss by the cowpea in the different fractional treatments while positive and negative controls also differed significantly $(\mathrm{P}>0.05)$ with all the partitioned treatments. Partition extracts from $Z$. zanthoxyloides were more bioactive than the crude powder, and n-hexane fractions contain the most active compounds against $C$. maculatus. n-hexane extract contain most active biomolecules to be explored for bioinsecticide formulation with high potency for development of new biopesticide, eliminate toxic components and increase ease of handling when compared to bulk crude plant material used by farmers.

Keywords: Zanthoxylum zanthoxyloides, Callosobruchus maculatus, toxicity, partitioned extracts, insecticidal activity

\section{Introduction}

One of the greatest challenges facing the human race today is food insecurity. With the world population estimate of 8 billion today and projected to reach 10 billion persons in the year 2055 and 11 billion in the year 2088 (UN, 2017), the need to double stable food production for the growing populace becomes paramount. In Africa 257 million people (20\%) are hungry and chronically undernourished and 28 African countries including Nigeria depends on food aid (Statista, 2020). One of the stable food crops and a major source of protein intake consumed world over and especially in Nigeria is cowpea (Vigna unguiculata (L) Walp.) (Leguminosae). Cowpea is the most important proteinous legume in West Africa responsible for between $60-80 \%$ protein intakes of its inhabitants; providing the only source of daily protein intake for a great number that cannot afford animal protein (Rajashekar et al., 2016; Mobolade et al., 2019). Annual production of cowpea (worldwide) is put at 7.4 million tonnes, with Nigeria accounting for 46\%, valued at US\$ 633,956,000 (Xiong et al., 2016; FAOSTAT, 2017; IITA, 2017). It is highly nutritive with $22 \%$ protein, $1.5 \%$ fat and $60 \%$ carbohydrate, and with protein digestibility higher than that of other legumes (Jayathilake et al., 2018).

The major constraint to availability of this crop and stable food for Nigerians is the menace of insect pests (about 130 species associated with cowpea production); the most important pest of cowpea is Callosobruchus maculatus (Fab.) (Coleoptera: Chrysomelidae) and is responsible for up to $100 \%$ damage to cowpea in storage (Xiong et al., 2016). Globally, insect damage to stored products range from 5-10\% in temperate climes and $20-30 \%$ in tropical zones (Ashamo et al., 2018).

Once infestation of pests (including C. maculatus) is established in stored products, the only alternative available to the farmer is to apply synthetic insecticide otherwise loss of the entire stored product is inevitable. Synthetic insecticides have become very popular since their discovery in the 1940s because of their efficacy, availability and ease of application even on 
large scale and they constitute man's first line of defence in pest outbreaks (Oni et al., 2018). As the world population hits 8 billion mark, there is growing need to double food production and this would lead to threefold increase in fertilizer and pesticide usage (IITA, 2017). The world agrochemical market was worth US\$ 243.1 billion in 2019 and projected to hit US\$300 billion in 2024; insecticides account for 25\% of this market (FAOSTAT, 2017; Statista, 2020). Unfortunately, the most deadly synthetic insecticides are used in Nigeria; these include Lindane, Malathion, Carbofuran, Dichlorvos, Chlorpyrifos, DDT, etc., (Ojo, 2016). Generally these insecticides have high mammalian toxicity, low biodegradability, pest resurgence and resistance, residue accumulation in farm products and soil, and the consequent environmental concerns. Another problem is the increasing cost of procurement in the wake of the dwindling farmers' income and value of local currency have rendered these insecticides too expensive with a call for switch to natural products (Ashamo et al., 2018).

Peasant farmers all over the world use plant materials for storage of their excess harvest as protectants against pest infestation (Oni et al., 2018). The past four decades have witnessed a new impetus in the development and evaluation of botanical insecticides in view of their relative safety to the environment (Soujanya et al., 2016; Singh, 2017; Spochacz, et al., 2018; Tazerouni et al., 2019). Many plants and plant parts (root, stem, stembark, leaves, fruits, etc.) have been screened with positive results for development of biopesticides (Ojebode et al., 2015; Gbaye et al., 2016; Ileke et al., 2017; Ashamo et al., 2018).

Zhang et al., (2017) reported that six essential oils from the genus Zanthoxylum have remarkable repellent activities against Tribolium castaneum and Lasioderma serricorne adults. Zhang et al., (2018) reported that out of eleven lignans extracted from stem bark of Zanthoxylum armatum, four compounds have strong antifeedant activity against $T$. castaneum. Osabutey et al., $(2015,2018)$ reported larvicidal potential of Z. zanthoxyloides in laboratory and field trials against Plutella xylostella. Buxton et al., (2017) isolated pellitorine from $Z$. zanthoxyloides as the main bioactive compound responsible for insecticidal activities against Sitophilus oryzae.

The use of partitioned extraction methodology in this study is to allow for identification of components with high potency for development of new biopesticide, eliminate toxic components and increase ease of handling when compared to bulk crude plant material used by farmers.

\section{Methods}

Root bark of Zanthoxylum zanthoxyloides and Vigna unguiculata (seeds) were obtained from Bida, Nigeria (latitude $9.6^{\circ}$ north and longitude $6.1^{\circ}$ east) and Z. zanthoxyloides was dully identified at National Institute of Pharmaceutical Research and Development (NIPRD) Abuja with voucher number NIPRD/H/7101. The plant was dried under laboratory conditions (ambient temperature of $34 \pm 6^{\circ} \mathrm{C}$ and relative humidity of $41 \pm 5 \%$ ). A stock specimen of $C$. maculatus was obtained from Biological Science Department of Federal Polytechnic, Bida. Analytical grade of solvents were obtained for the work.

\subsection{Preparation of Extracts}




\section{Macrothink}

Journal of Agricultural Studies

ISSN 2166-0379

2021, Vol. 9, No. 3

The root bark of $Z$. zanthoxyloides was grounded into fine powder (using electric blender; $\mathrm{CM} / \mathrm{L}-7480681$ and sieved using $1 \mathrm{~mm}^{2}$ mesh) and $1000 \mathrm{~g}$ (weighed with Ohaus analytical balance PA214 and Labtech BL7501; China) was used for partitioned extraction using modified Kupchan partition methodology (Emran, et al., 2015). The following solvents were used for partition extraction; methanol, acetone, ethyl acetate and hexane in order of decreasing polarity. Soxhlet extraction apparatus, water bath DK600 and rotary evaporator RE-6000 (China) were used for extraction and evaporation.

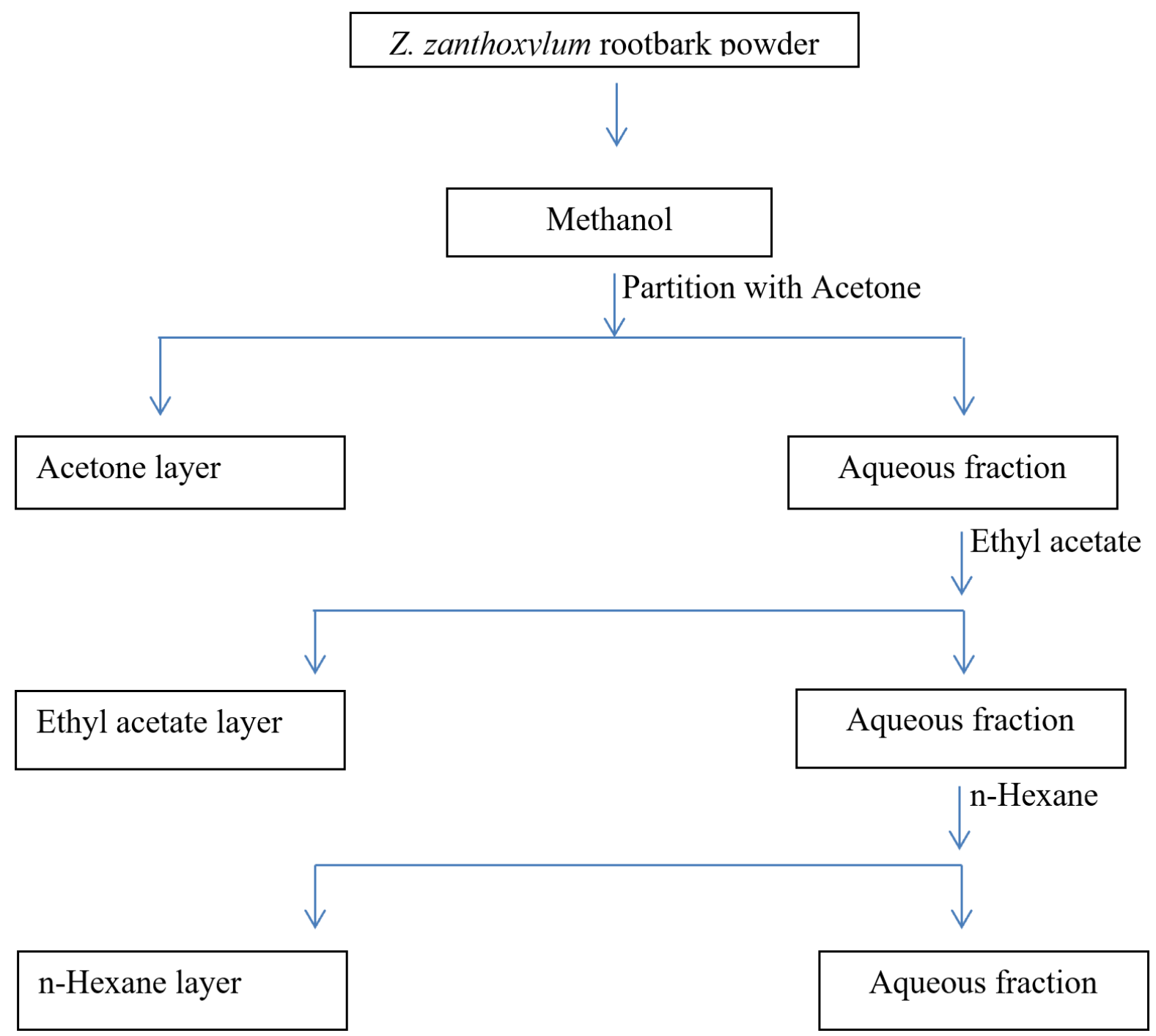

Figure 1. Schematic representation of modified Kupchan partition methodology

\subsection{Proximate, Phytochemical and Mineral Composition Analysis}

Determination of percentage moisture, ash, crude protein, crude fibre, oil extract and nitrogen free extract (NFE) of root bark of Z. zanthoxyloides was carried out by AOAC (1995) standard methods. Phytochemical screening was done in accordance with Harbone (1973) methods. Mineral analysis was done using Buck Scientific Atomic Absorption/Emission Spectrophotometry (AAS) and molybdemun blue method for phosphorus. UV-visible 
spectrophotometer Shimadzu UV1800 (Japan) was utilized.

\subsection{Bioassay}

$20 \mathrm{~g}$ of cowpea was weighed into each of the 51 plastic containers. Each partitioned extract of Z. zanthoxyloides (methanol, acetone, ethyl acetate and n-hexane) was applied at 1\%,2\% and $3 \%$ to the cowpea in the plates and thoroughly mixed, and every concentration for each extract was replicated three times. Crude powder of the root bark of Z. zanthoxyloides was applied at $0.5 \mathrm{~g}, 1.0 \mathrm{~g}$ and $1.5 \mathrm{~g}$ to $20 \mathrm{~g}$ of cowpea and each concentration replicated three times. Positive control was set up using Dichlorovinyl dimethyl phosphate (Sniper) and a negative control (without extract or powder) was also set up and replicated three times. Five (5) pairs of $C$. maculatus was added to each plate (i.e. 5 males and 5 females) and allowed to oviposit for seven days following inoculation. The set up was left at ambient laboratory conditions for observation and monitored for oviposition.

Toxicity test was carried out by dipping method (Paramasivam and Selvi, 2017), the insects were returned to food source and mortality was measured over a period of five days. Mortality was calculated using Abbott's formula:

$$
C M=\left[\frac{M T-M C}{100-M C}\right] 100
$$

$\mathrm{CM}=$ Corrected mortality

MT $=$ Mortality in test

$\mathrm{MC}=$ Mortality in control

Four parameters were measured; toxicity, number of adults emerged (number of adult insect emerging in first filial generation), weight loss and viability test of seeds (percentage germination of cowpea). Weight loss and Percentage germination were calculated as follows:

$$
W L=\left[\frac{O W-F W}{O W}\right] 100
$$

$\mathrm{WL}=$ Weight loss

$\mathrm{OW}=$ Original weight

$\mathrm{FW}=$ Final weight

$$
P G=\left[\frac{N S G}{T S P}\right] 100
$$

$\mathrm{PG}=$ Percentage germination

$\mathrm{NSG}=$ Number of seeds that germinated 
TSP $=$ Total number of seeds planted

\section{Data Analysis}

Data obtained for toxicity was transformed using Abbott's formula. Other data were subjected to one way Analysis of Variance (ANOVA) and Tukey's Multiple Comparison Test (SPSS version 21 and Graphpad Prism version 8.0).

\section{Results}

\subsection{Proximate, Phytochemical and Mineral Composition Analysis}

Proximate analysis of root bark of $Z$. zanthoxyloides revealed $7.46 \%$ moisture content, $19.87 \%$ ash content, $7.00 \%$ crude protein, $24.85 \%$ crude fibre, $3.13 \%$ oil extract and $37.69 \%$ NFE (Table 1)

Table 1. Proximate analysis of root bark of Z. zanthoxyloides

\begin{tabular}{lcccccc}
\hline Sample & $\begin{array}{c}\% \\
\text { Moisture }\end{array}$ & $\begin{array}{c}\text { \% Ash } \\
\text { content }\end{array}$ & $\begin{array}{c}\text { \% Crude } \\
\text { protein }\end{array}$ & $\begin{array}{c}\text { \% Crude } \\
\text { fibre }\end{array}$ & $\begin{array}{c}\text { \% Oil } \\
\text { extract }\end{array}$ & \% NFE \\
\hline $\begin{array}{l}\text { Z. } \\
\text { anthoxyloides }\end{array}$ & 7.46 & 19.87 & 7.00 & 24.85 & 3.13 & 37.69 \\
\hline
\end{tabular}

NFE: Nitrogen free extract (carbohydrate)

Phytochemical analysis (Table 2) showed that root bark of Z. zanthoxyloides contained $15.42 \mathrm{mg} / 100 \mathrm{~g}$ alkaloids, $45.90 \mathrm{mg} / 100 \mathrm{~g}$ of Tannins, $1039.14 \mathrm{mg} / 100 \mathrm{~g}$ of Saponins, $26.47 \mathrm{mg} / 100 \mathrm{~g}$ of Flavonoids and $7630.04 \mathrm{mg} / 100 \mathrm{~g}$ of reducing sugar.

Table 2. Phytochemicals analysis of root bark of Z. zanthoxyloides

\begin{tabular}{lccccc}
\hline Sample & Alkaloids & Tannins & Saponins & Flavonoids & $\begin{array}{c}\text { Reducing } \\
\text { sugar }\end{array}$ \\
\hline $\begin{array}{l}\text { Z. zanthoxyloides } \\
\text { (mg/100g) }\end{array}$ & 15.42 & 45.90 & 1039.14 & 26.47 & 7630.04 \\
\hline
\end{tabular}

Mineral analysis of root bark of Z. zanthoxyloides indicated it contained $150.00 \mathrm{mg} / 100 \mathrm{~g}$ of Iron, $244.70 \mathrm{mg} / 100 \mathrm{~g}$ of Calcium, 36.65mg/100g of Magnesium, $24.20 \mathrm{mg} / 100 \mathrm{~g}$ of Sodium, $449.00 \mathrm{mg} / 100 \mathrm{~g}$ of Potassium, and 128.30mg/100g of Phosphorus (Table 3).

Table 3. Mineral analysis of root bark of Z. zanthoxyloides

\begin{tabular}{lllllll} 
Sample & Iron & Calcium & Magnesium & Sodium & Potassium & Phosphorous \\
\hline $\begin{array}{l}\text { Z. } \\
\text { zanthoxyloides } \\
\text { (mg/100g) }\end{array}$ & 150.00 & 244.70 & 36.65 & 24.20 & 449.00 & 128.30 \\
\hline
\end{tabular}




\subsection{Bioassay}

The result of toxicity test showed that n-hexane extract at $1 \%, 2 \%$ and $3 \%$, acetone extract at $3 \%$, and crude powder at $1.5 \mathrm{~g}$ all had same effect on the insect as the positive control, achieving $100 \%$ mortality at 24 hours post treatment (Table 4). All treatments of methanol extract was only able to achieved $90 \%$ mortality after 120 hours, all treatment of acetone extract achieved $100 \%$ mortality at 120 hours while ethyl acetate did the same under 96 hours.

Table 4. Percentage mortality of Callosobruchus maculatus post treatment

\begin{tabular}{|c|c|c|c|c|c|c|c|}
\hline TREATMENT & & OHR & 24HR & 48HR & 72HR & 96HR & 120HR \\
\hline \multirow{3}{*}{ METHANOL EXTRACT } & $1 \%$ & 0.00 & $10.00 \mathrm{~g}$ & $10.00 \mathrm{f}$ & $40.00 \mathrm{f}$ & $70.00 \mathrm{c}$ & $80.00 \mathrm{c}$ \\
\hline & $2 \%$ & 0.00 & $20.00 \mathrm{f}$ & $20.00 \mathrm{e}$ & $50.00 \mathrm{e}$ & $80.00 \mathrm{~b}$ & $90.00 \mathrm{~b}$ \\
\hline & $3 \%$ & 0.00 & $40.00 \mathrm{e}$ & $40.00 \mathrm{~d}$ & $60.00 \mathrm{~d}$ & $70.00 \mathrm{c}$ & $90.00 \mathrm{~b}$ \\
\hline \multirow{3}{*}{ ACETONE EXTRACT } & $1 \%$ & 0.00 & $50.00 \mathrm{~d}$ & $70.00 \mathrm{~b}$ & $70.00 \mathrm{c}$ & $80.00 \mathrm{~b}$ & $100.0 \mathrm{a}$ \\
\hline & $2 \%$ & 0.00 & $70.00 \mathrm{c}$ & $100.00 \mathrm{a}$ & $100.00 \mathrm{a}$ & $100.00 \mathrm{a}$ & $100.0 \mathrm{a}$ \\
\hline & $3 \%$ & 0.00 & $100.00 \mathrm{a}$ & $100.00 \mathrm{a}$ & $100.00 \mathrm{a}$ & $100.00 \mathrm{a}$ & $100.0 \mathrm{a}$ \\
\hline \multirow{4}{*}{ ETHYL ACETATE } & $1 \%$ & 0.00 & $20.00 \mathrm{f}$ & $40.000 \mathrm{~d}$ & $80.00 \mathrm{~b}$ & $100.00 \mathrm{a}$ & $100.0 \mathrm{a}$ \\
\hline & $2 \%$ & 0.00 & $80.00 \mathrm{~b}$ & $100.00 \mathrm{a}$ & $100.00 \mathrm{a}$ & $100.00 \mathrm{a}$ & $100.0 \mathrm{a}$ \\
\hline & $3 \%$ & 0.00 & $80.00 \mathrm{~b}$ & $100.00 \mathrm{a}$ & $100.00 \mathrm{a}$ & $100.00 \mathrm{a}$ & $100.0 \mathrm{a}$ \\
\hline & $1 \%$ & 0.00 & $98.33 \mathrm{a}$ & $100.00 \mathrm{a}$ & $100.00 \mathrm{a}$ & $100.00 \mathrm{a}$ & $100.00 \mathrm{a}$ \\
\hline \multirow[t]{2}{*}{ N-HEXANE } & $2 \%$ & 0.00 & $100.00 \mathrm{a}$ & $100.00 \mathrm{a}$ & $100.00 \mathrm{a}$ & $100.00 \mathrm{a}$ & $100.00 \mathrm{a}$ \\
\hline & $3 \%$ & 0.00 & $100.00 \mathrm{a}$ & $100.00 \mathrm{a}$ & $100.00 \mathrm{a}$ & $100.00 \mathrm{a}$ & $100.00 \mathrm{a}$ \\
\hline \multirow{2}{*}{ CRUDE POWDER } & $0.5 \mathrm{~g}$ & 0.00 & $40.00 \mathrm{e}$ & $40.00 \mathrm{~d}$ & $60.00 \mathrm{~d}$ & $70.000 \mathrm{c}$ & $90.00 \mathrm{~b}$ \\
\hline & $1.0 \mathrm{~g}$ & 0.00 & $50.00 \mathrm{~d}$ & $50.00 \mathrm{c}$ & $69.33 c$ & $100.00 \mathrm{a}$ & $100.00 \mathrm{a}$ \\
\hline \multirow{3}{*}{$\begin{array}{l}\text { POSITIVE CONTROL } \\
\text { NEGATIVE CONTROL }\end{array}$} & $1.5 \mathrm{~g}$ & 0.00 & $100.00 \mathrm{a}$ & $100.00 \mathrm{a}$ & $100.00 \mathrm{a}$ & $100.00 \mathrm{a}$ & $100.00 \mathrm{a}$ \\
\hline & & 0.00 & $100.00 \mathrm{a}$ & $100.00 \mathrm{a}$ & $100.00 \mathrm{a}$ & $100.00 \mathrm{a}$ & $100.00 \mathrm{a}$ \\
\hline & & 0.00 & $0.00 \mathrm{~h}$ & $0.00 \mathrm{~g}$ & $0.00 \mathrm{~g}$ & $0.00 \mathrm{~d}$ & $0.00 \mathrm{~d}$ \\
\hline
\end{tabular}

Values with different small letters within the columns are significantly different $(\mathrm{Fpr}$. $<0.05)$. based on Multiple Comparison Test following ANOVA. HR = Hour

Figure 2 shows adult emergence in F1 generation. The extracts reduced number of adult emergence with increasing concentration: methanol extracts from 63.57 in $1 \%$ treatment to 28 in $3 \%$ treatment, acetone extract from 52 in $1 \%$ treatment to 17 in $3 \%$ treatment, ethyl acetate from 46 in $1 \%$ treatment to 14 in $3 \%$ treatment, n- Hexane extract and positive control reduced number of adult emergence to zero while in negative control 95 adults emerged (these result were significantly different at $p<0.05$ ).

Weight loss by cowpea showed similar variation: in methanol extract it varied from $0.73 \mathrm{~g}$ in $1 \%$ treatment to $0.43 \mathrm{~g}$ in $3 \%$ treatment, in acetone extract from $0.83 \mathrm{~g}$ in $1 \%$ treatment to $0.57 \mathrm{~g}$ in $3 \%$ treatment, in ethyl acetate extract from $0.87 \mathrm{~g}$ in $1 \%$ treatment to $0.56 \mathrm{~g}$ in $3 \%$ treatment, $\mathrm{n}$-hexane did better than the positive control with values of $0.23 \mathrm{~g}$ in $1 \%$ treatment, $0.13 \mathrm{~g}$ in $2 \%$ treatment and $0.1 \mathrm{~g}$ in $3 \%$ treatment while positive control had $0.33 \mathrm{~g}$ (Figure 3 ).

Figure 4 shows the viability of the cowpea seeds after F1 emergence, expressed as percentage germination. Percentage germination of cowpea after adult emergence showed that methanol extract varied from $73 \%$ in $1 \%$ treatment to $86 \%$ in $3 \%$ treatment, acetone extract from $63 \%$ in $1 \%$ treatment to $76 \%$ in $3 \%$ treatment ethyl acetate extract from $63 \%$ in $1 \%$ treatment to $76 \%$ in $3 \%$ treatment, n-hexane extract from $96 \%$ in $1 \%$ treatment to $100 \%$ in $2 \%$ and $3 \%$ treatments, similar values were obtained from positive control. The negative control gave $23 \%$ germination. 


\section{Macrothink}

The effect of crude powder of Z. zanthoxyloides is shown in Figure 5. Crude powder applied at $0.5 \mathrm{~g}, 1.0 \mathrm{~g}$ and $1.5 \mathrm{~g}$ gave 29,22 and 14 for number of adult emergence, $0.47 \mathrm{~g}, 0.5 \mathrm{~g}$ and $0.43 \mathrm{~g}$ for weight loss, $76 \%, 80 \%$ and $83 \%$ for germination respectively.

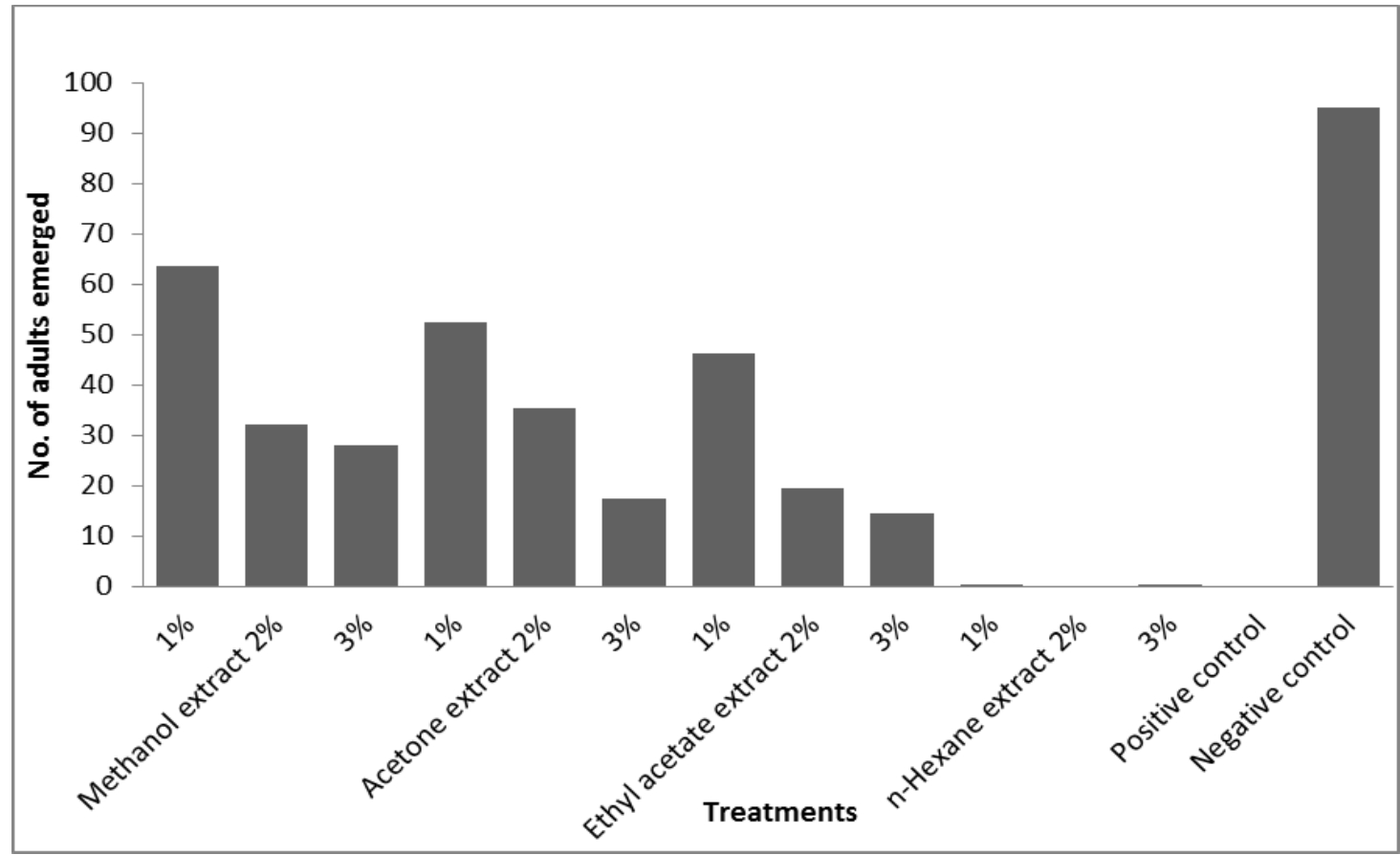

Figure 2. Effect of partitioned extracts on adult emergence

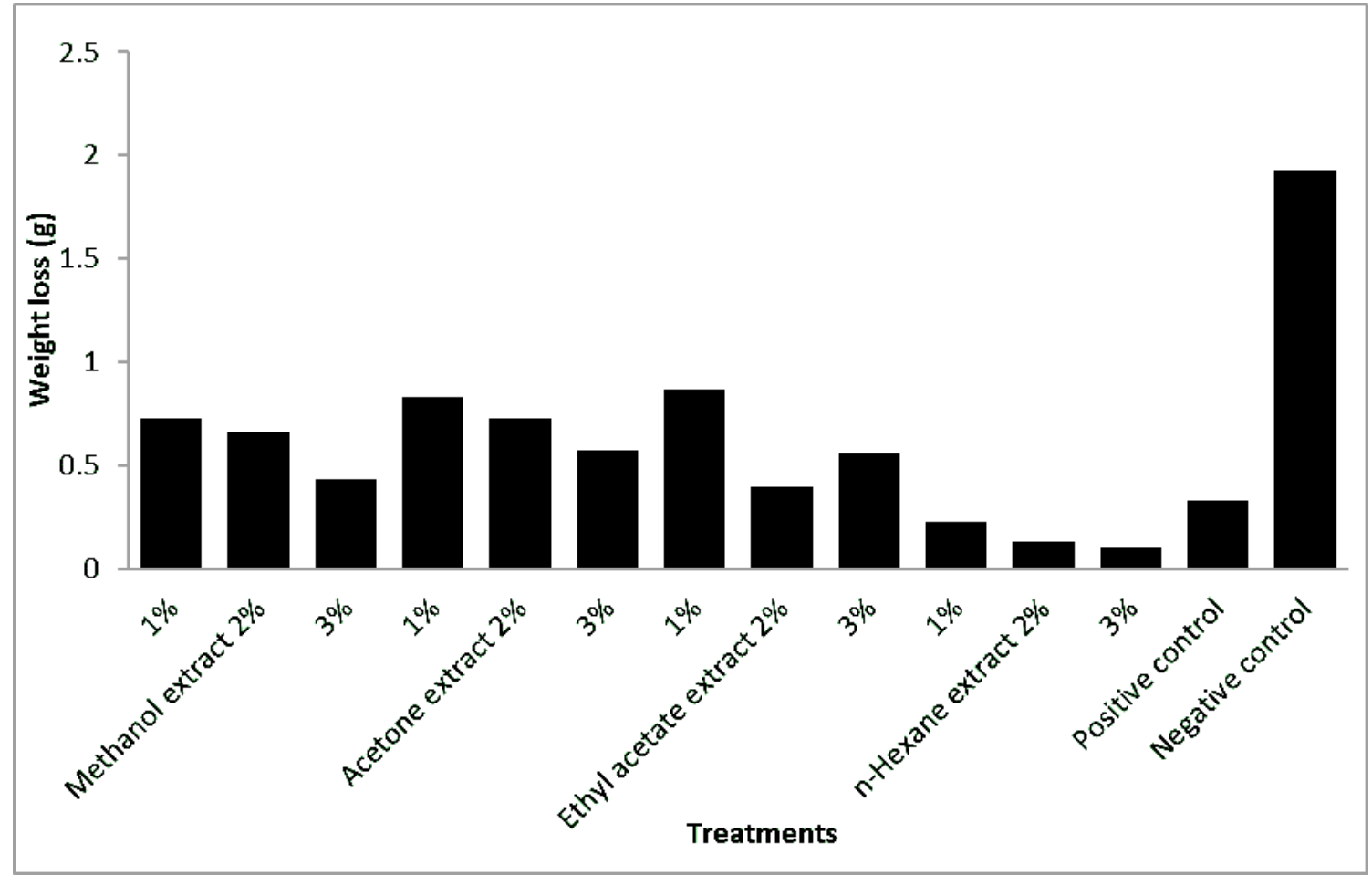

Figure 3. Effect of partition extracts on weight loss 


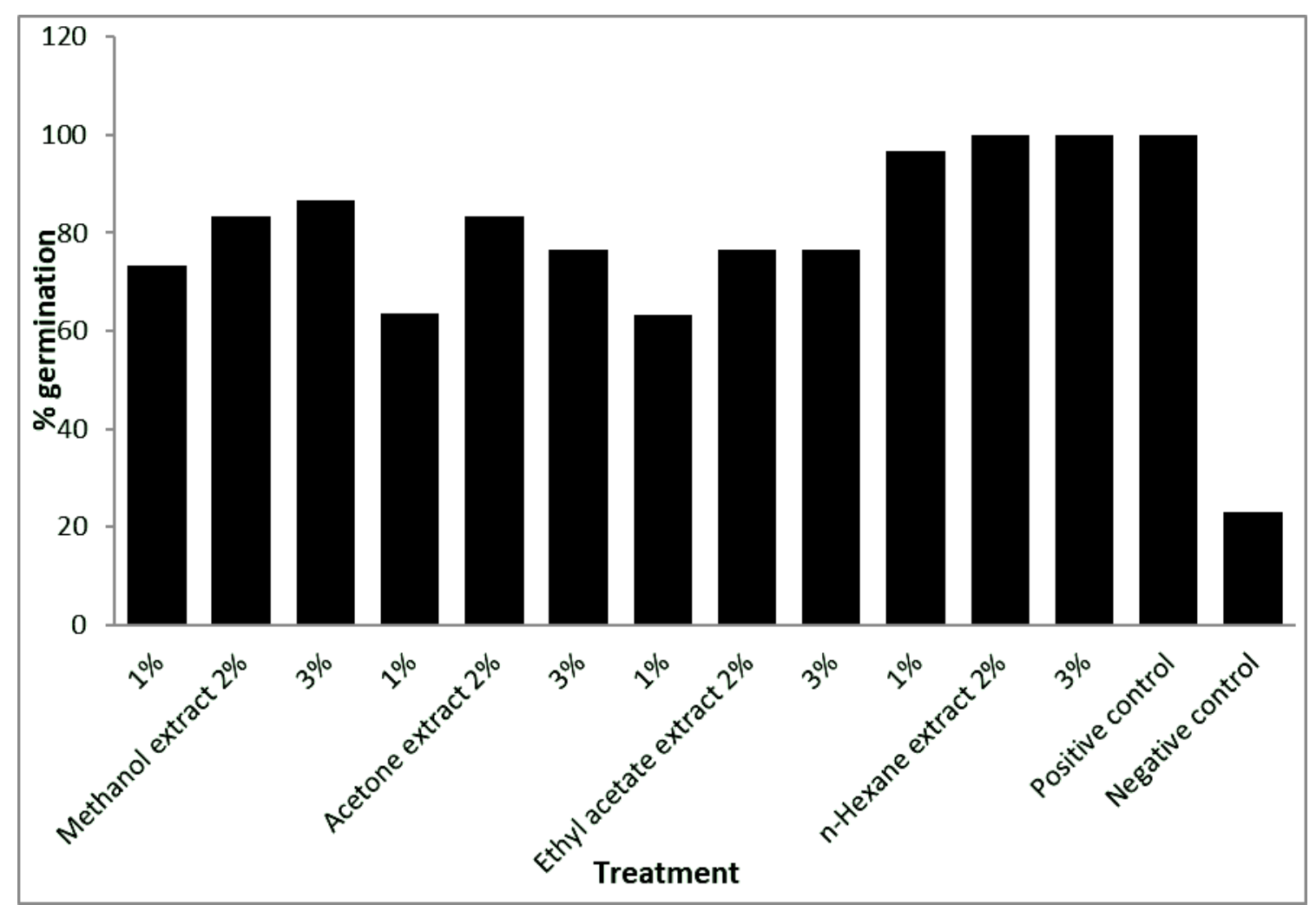

Figure 4. Effect of partition extracts on germination

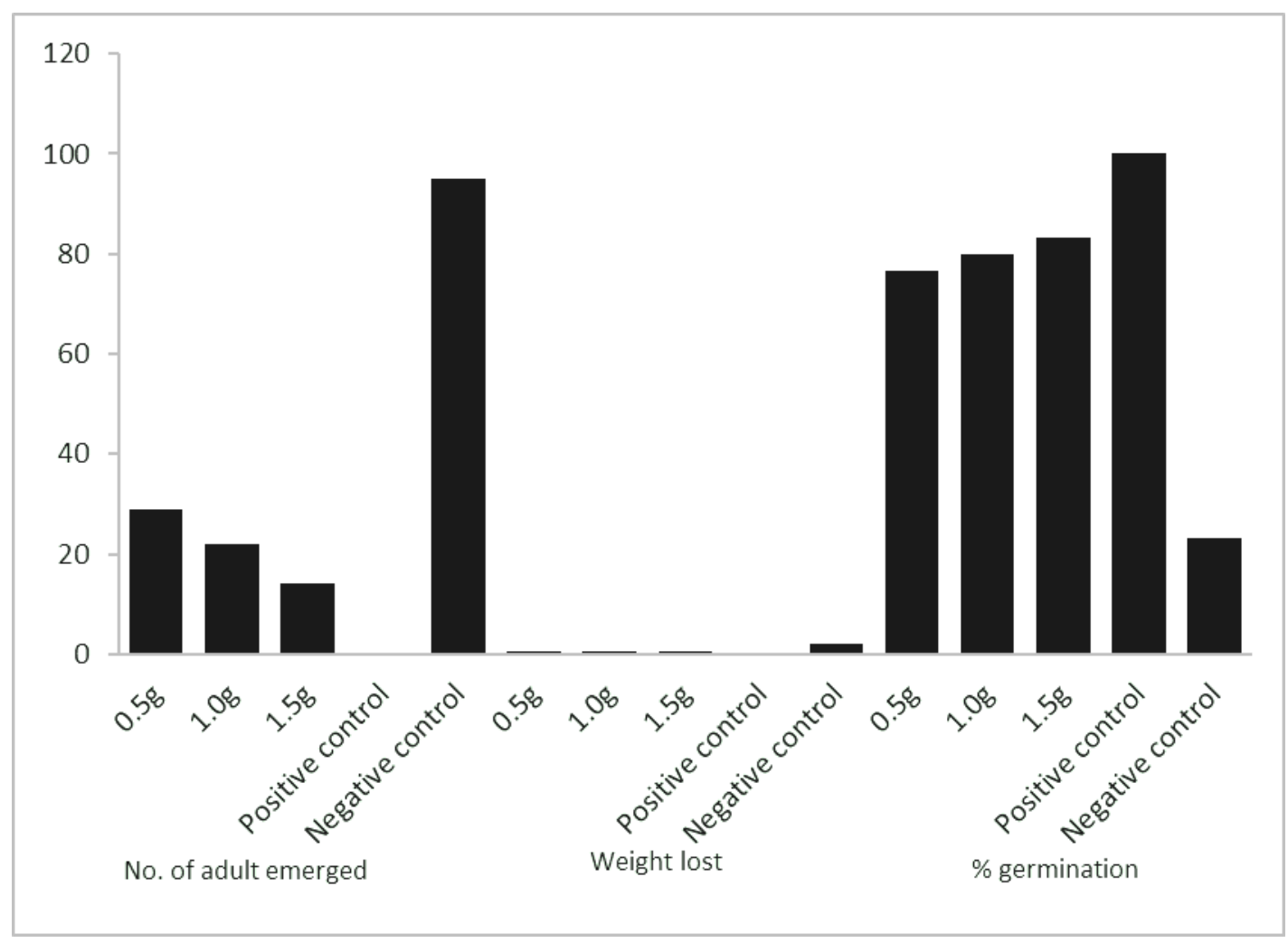

Figure 5. Effect of crude powder on C. maculatus 


\section{Discussion}

The result for proximate and elemental analysis corresponds to those obtained by Ilodibia et al. (2017) working on stem of Z. zanthoxyloides. Results obtained for the phytochemical analysis were quite different from those of Aworinde et al. (2016); their values were all higher except for saponins where $1039.14 \mathrm{mg} / 100 \mathrm{~g}$ was obtained compared to $378.33 \mathrm{mg} / 100 \mathrm{~g}$. This can be attributed to the differences in the part analysed (root and stem, respectively).

n-hexane extract achieved $100 \%$ mortality within 24 hours, this is consistent $100 \%$ mortality obtained by Buxton et al. (2017) using crude powder and methanolic extract of $Z$. zanthoxyloides as contact insecticide against C. maculatus, Sitophilus oryzae, Oryzaephilus mercator and Rhyzopertha dominica respectively; Ojebode et al. (2016) using essential oil of Cymbopogon citratus and Citrus sinensis and Ileke et al. (2017) using leaves and seed extract of Aframomum meleaguta.

Suppression of adult emergence and weight loss, and percentage germination of cowpea seeds were all highest in n-hexane extract, the values here compared well with those obtained for positive control and collaborates results obtained by Buxton et al. (2017) and Ashamo et al. (2018). All the partitioned extracts did better in terms of weight loss, germination capacity and adult emergence than results reported in Obembe and Ogundipe (2017) which neither achieved 100\% mortality after 96 hours nor reduced weight loss by same magnitude. The performance of extracts increased with increasing concentration in conformity with earlier works (Ileke et al., 2017 and Ashamo et al., 2018). This is indicative of the fact that all the partitioned extracts and particularly n-hexane component of the partitioned extracts contained secondary metabolites which are responsible for the effect exhibited in this study. Such secondary metabolites associated with $Z$. zanthoxyloides may be responsible for insecticide activity; repellence, mortality, anti-feeding, anti-oviposition, anti-morphogenesis, etc. Some of these metabolites already identified include: zanthoxylol (Elujoba and Nagels, 1985), benzophenanthridine, furoquinoline, aporphine alkaloids and several aliphatic amides (Matu, 2011), pellitorine, (Aruda et al., 1994; Buxton et al., 2017), several chemical compounds from oils of six species of Zanthoxylum (Zhang et al., 2017). The current study will add to the number of insecticidal compounds for Zanthoxylum as we explore the compounds in the most active extract ( $\mathrm{n}$-hehane extract) of $Z$. zanthoxyloides.

\section{Conclusion}

This result shows that $n$-hexane extract contains the most active ingredients as insecticide against $C$. maculatus (comparable to positive control) and had no negative impact on the germination of cowpea seeds. The work provides valuable evidence for the potential of $\mathrm{n}$-hexane extract in development and commercialization of novel pesticides in the future. The focus of future work would be on characterisation, purification and formulation of the active ingredients for use by our industries and farmers.

\section{References}

AOAC, (1995). Methods of Analysis of Association of official Analytical chemistry (15th ed.), Washington D.C. pp 600-792. 
Aruda, M. S. P., Fernandes, J. B., Vieira, P. C., Das, G. F., da Silva, F. M., \& Prani, J. R. (1994). Protolimonoid and lignans from Zanthoxylum petiolare, Phytochemistry, 36, 1303. https://doi.org/10.1016/S0031-9422(00)89656-9

Ashamo, M. O., Ogungbite, O. C., \& Adetogo, T. A. (2018). Insecticidal potency of Newbouldia laevis oil extracts against Sitrotoga cerealella, an importantpest of paddy rice, International Journal of Horticulture, 8(9), 98-105. https://doi.org/10.5376/ijh.2018.08.0009

Aworinde, D. O., Erinoso, S. M., \& IbukunOluwa, M. R. (2016). Mineral compositions, phytochemical constituents and in vitro antimicrobial screening of some chewing sticks from Ibadan, South-western Nigeria. J. Appl. Biosci., 101, 9589-9597. https://doi.org/10.4314/jab.v101i1.3

Bindhu, V.R., Ganga, S. \& Susha, D. (2015). Mortality Effects of Some Medicinal Plants on the Pulse Beetle Callosobruchus chinensis (Coleoptera: Bruchidae). J Biofertil Biopesticide, 6(1), 150. https://doi.org/10.4172/2155-6202.1000150

Buxton, T., Takahashi, S., Takakura, M., Niwata, I., Owusu, E.O. \& Kim, C. (2017). Insecticidal activities of pellitorine isolated from Zanthoxylum zanthoxyloides roots against Sitophilus oryzaeL. (Coleoptera: Curculionidae). Journal of Entomology and Zoology Studies, 5(3), 163-168.

Elujoba, A. A., \& Nagels, L. (1985). Chromatographic isolation and estimation of zanthoxylol: an antisickling agent from the roots of Zanthoxylum species, Journal of Pharmaceutical \& Biomedical Analysis, 3(5), 447-451. https://doi.org/10.1016/0731-7085(85)80059-5

Emran, T. B., Rahman, A., Uddin, M. N., Rahman, M., Uddin, Z., Dash, R., \& Layzu, C. (2015). Effects of organic extracts and their different fractions of five Bangladeshi plants on in vitro thrombolysis. BMC Complementary and Alternative Medicine, 15, 128. https://doi.org/10.1186/s12906-015-0643-2

FAOSTAT (Food and Agriculture Organization of the United Nations) (2017). Cowpea Production \& Pesticides Use. Retrieved from

http://www.fao.org/faostat/en/\#data/RP,5/12/2017

Gbaye, O. A., Oyeniyi, E. A., \& Eweniyi, J. T. (2016). Mothcidal activity of three botanical extracts against Sitotroga cerealella (Olivier, 1789) (Lepidoptera: Gelechiidae) infesting rice grains, Braz. J. Biol. Sci., 3(6), 367-374. https://doi.org/10.21472/bjbs.030612

Harborne, J. B. (1973). Phytochemical Methods 3rd ed. Chapman and Hall Ltd. 135-203

IITA (2017). International Institute of Tropical Agriculture Cowpea: Vigna Unguiculata https://www.iita.org/cropsnew/cowpea/

Ileke, K. D., Adesina, J. M., \& Okunola, O. G. (2017). Larvicidal and Pupicidal Potential of Aframomum melegueta K. Schum Extracts against Mosquito, Anopheles Species. J. Entomol. Res. Soc., 19(1), 121-127. 
Ilodibia, C. V., Nnaji, E., Aziagba, B. O., \& Ezeabara, C. A. (2017). Morphological and nutritional assessment of leaf, stem and root of Zanthoxylum macrophylla (Rutaceae). Archives of Agriculture and Environmental Science, 2(1), 44-46.

Jayathilake, C., Visvanathan, R., Deen, A., Bangamuwage, R., Jayawardana, B. C., Nammic, S., \& Liyanagea, R. (2018). Cowpea: an overview on its nutritional factsand health benefits. $J$ Sci Food Agric., 9074. https://doi.org/10.1002/jsfa.9074

Mobolade, A. J., Bunindrob, N., Sahoob, D., \& Rajashekarb, Y. (2019). Traditional methods of food grains preservation and storage in Nigeria and India. Annals of Agricultural Sciences, 64,196-205. https://doi.org/10.1016/j.aoas.2019.12.003

Obembe, O. M., \& Ogungbite, O. C. (2017). Biotoxicity of different parts of Anacardium occidentale (Linn.) against Callosobruchus maculatus (F.) infestation on stored cowpea seeds. International Journal of Horticulture, 7(9), 64-75. https://doi.org/10.5376/ijh.2017.07.0009

Ojebode, M. E., Olaiya, C. O., Adegbite, A. E., Karigidi, K. O., \& Ale, T. O. (2016). Efficacy of Some Plant Extracts as Storage Protectants against Callosobruchus maculatus. J Biotechnol \& Biomater, 6, 217. https://doi.org/10.4172/2155-952X.1000217

Ojo, J. (2016). Pesticides use and Health in Nigeria. Ife Journal of Science, 18(4), 981-991.

Oni, M. O., Ogungbite, O. C., \& Ofuya, T. I. (2018). Biotoxic efficacy of different fractions of Acalypha godseffiana oil extracts against Callosobruchus maculates infesting stored Cowpea. Medicinal Plant Research, 8(2), 8-13. https://doi.org/10.5376/mpr.2018.08.0002

Osabutey, A. F., Eziah, V., \& Owusu, E. O. (2015). Larvicidal effect of methanol extracts of Zanthoxylum zanthoxyloides (lam) against the diamond back moth, Plutella xylostella (L) (Lepidoptera: Plutellidae) on Cabbage, J. Ghana Sci. Ass., 16(2).

Osabutey, A. F., Vincent, E. V., Buxton, T., \& Owusu, E. O. (2018). Evaluating the insecticidal potential of aqueous plant extracts from Zanthoxylum zanthoxyloides and Anacardium occidentale against insect pest complexes of cabbage in an open field experiment. Int. J. Agric. Sc. Research, 7(3), 018-027.

Paramasivam, M. \& Selvi, C. (2017). Laboratory bioassay methods to assess the insecticide Rajashekar, Y., Tonsing, N., Shantibala, T., \& Manjunath, J. R. (2016). 2, 3-Dimethylmaleic anhydride (3, 4-Dimethyl-2, 5-furandione): a plant derived insecticidal molecule from Colocasia esculenta var. esculenta (L.) Schott Sci. Rep., 6, 20546. https://doi.org/10.1038/srep20546

Singh, S. (2017). Natural plant products - As protectant during grain storage: A review, Journal of Entomology and Zoology Studies, 5(3), 1873-1885.

Soujanya, P. L., Sekhar, J. C., Kumar, P., Sunil, N., Prasad, C. V., \& Mallavadhani, U. V. (2016). Potentiality of botanical agents for the management of post harvest insects of maize: a review. J. Food Sci Technol., 53(5), 2169-2184. https://doi.org/10.1007/s13197-015-2161-0

Spochacz, M., Chowa'nski S., Walkowiak-Nowicka, K., Szymczak, M., \& Adamski, Z. 
(2018). Plant-Derived Substances Used Against Beetles Pests of Stored Crops and Food and Their Mode of Action: A Review Comprehensive Reviews, Food Science and Food Safety, 17, 1339-1366. https://doi.org/10.1111/1541-4337.12377

Statista (2020). Global agricultural chemical market value 2019 \& 2024. https://www.statista.com/statistics/311943/agrochemical-market-value-worldwide/retrieved27 $/ 05 / 2020$

Tazerouni, Z., Rezaei, M., \& Talebi, A. A. (2019). Cowpea: Insect Pest Management In: Agricultural Research Updates: Volume 26. Editors: Prathamesh Gorawala et al. Nova Science Publishers, Inc. Tehran, Iran pp 2-48 ISBN: 978-1-53614-930-2

UN (2017). World Population Prospects: the 2017 revision https://esa.un.org/undp/wpp/retrieved 19/05/18

Xiong, H., Shi, A., Mou, B., Qin, J., Motes, D., Lu, W., Ma, J., Weng, Y., \& Yang, W. (2016). Genetic Diversity and Population Structure of Cowpea (Vigna unguiculata L. Walp). PLOS ONE, 11(8). https://doi.org/10.1371/journal.pone.0160941

Zhang, W., Wang, Y., Geng, Z., Guo, S., Cao, J., Zhang, Z., ... Deng, Z. (2018). Antifeedant Activities of Lignans from Stem Bark of Zanthoxylum armatum DC. Against Tribolium castaneum, Molecules, 23(617), 1-10. https://doi.org/10.3390/molecules23030617

Zhang, W., Zhang, Z., Chen, Z., Liang, J., Geng, Z., Guo, S., Du, S. \& Deng, Z. (2017). Chemical composition of essential oils from six Zanthoxylum species and their repellent activities against two stored-product insects, Journal of Chemistry, 1-7. https://doi.org/10.1155/2017/1287362

\section{Copyright Disclaimer}

Copyright for this article is retained by the author(s), with first publication rights granted to the journal.

This is an open-access article distributed under the terms and conditions of the Creative Commons Attribution license (http://creativecommons.org/licenses/by/4.0/). 